\title{
ENHANCING CAPACITY FOR LOCAL ECONOMIC DEVELOPMENT IN CREATING VIBRANT, PRODUCTIVE AND SUSTAINABLE RURAL COMMUNITIES
}

\author{
Gail Denise Parker (PhD) \\ parkergd@researchglobal.net \\ King Costa (PhD) \\ costak@researchglobal.net
}

Affiliation: South Valley University (SVU) and Global Centre for Academic Research (GCAR)

Abstract

Since the advent of South Africa's democracy, there have been many pressing questions; one of which has been: 'to what extent has the newly found politicaland civil freedoms, which is guaranteed for all South Africans, translated into an amore economically-viable life?' This research investigated whether local economic development (LED) interventions necessarily improve the livelihoods of poor communities. The methods used were hinged upon the interpretivist paradigm, using literature as a basis of enquiry. Furthermore, semi-structured interviews with target groups (eg. project beneficiaries, government officials, municipal manager, town mayor, etc) were conducted, followed by focus group-style interviews with key stakeholders. The study found that sound economic development vision may thrive if linked to the following: clear policy guidance, institutional capacity building, intersectoral collaboration, political will and real empowerment.

Key words: Economic activity, Empowerment initiative, Local economic development, Policy guidance, Intersectoral collaboration 


\subsection{INTRODUCTION}

As one way of redressing the racial imbalances caused by the apartheid policies, the post-apartheid government has committed itself to, amongst others, building local economies and creating jobs (ANC, 1994). In line with this commitment, the new government - which is led by the African National Congress (ANC) - has put in place the legislative framework that should enable people to create better lives for themselves. As the country enters its second decade of democracy and freedom, it is perhaps the most appropriate time to evaluate whether the government has made any significant gains in its goal of improving the lives of its poorest citizens. A crucial question since the advent of democracy in South Africa is 'to what extent has the newly found political and civil freedoms, which is guaranteed for all South Africans, translated into a more economically-viable life?' If the remarks of the Minister of Finance (1994 to 2004 and then appointed to serve another five-year term in 2004), Trevor Manuel, are true, in which he stated that "the policies have thus far not generated the anticipated levels of development," (Sunday Times, January 2000, as quoted by Nel and Binns, 2001), then there is a need to investigate why this is the case.

It is common knowledge that the ANC-led government inherited a country with a very skewed economy. Most, if not all, of the crucial economic resources of the country are concentrated in urban areas, while very few economic activities and resources are found in their rural counterpart. This has led to minimal or no growth taking place in rural towns. It is therefore not a surprise that almost 70 percent of the country's poorest people reside in rural areas (Aliber, 2002). Poverty manifests itself in various forms in communities. However, what is very common to all poor communities in South Africa is the fact that they have limited opportunities for economic development and have thus become trapped in a poverty circle (Tickamyer, 1990). The only way of

addressing poverty is economic growth. Hence the response of government to this "retarded economic development" (Binns and Nel, 2002), became the policy of local economic development (LED). This policy gives life to the mandate given to local municipalities by the Constitution, which is "to promote social and economic development" (Section 152 of the Constitution of the Republic of South Africa, Act 108 of 1996). The challenge that this research wishes to explore is to what extent this is in fact possible or even true. In other words, this study seeks to establish 
whether LED interventions can necessarily bring about improved livelihoods of poor communities. A further challenge was to determine the extent of successful achievement of local economic objectives in towns where land and an abundance of unskilled labour are some of the very few resources that are available for improving local economies. This is in spite of the fact that LED is regarded as the tool to develop poor communities. This notion originates countries in in the northern hemisphere (Nel 2001), where it was seen as a "response to the so-called development impasse. Countries in the southern hemisphere, South Africa in particular, adopted a similar approach. Today, LED “enjoys wide acceptance and credibility” (Nel, 2001).

The Northern Cape is the poorest province in the country and is outdone only by the Eastern Cape and Limpopo provinces. Land-based local economic development strategies therefore became the focus of this study. The study made the assumption that when local municipalities develop their Integrated Development Plans (IDP), as prescribed by the Municipal Systems Act (Act No. 32 of 2000), insufficient consideration is given to the potential that land has in stimulating and sustaining the local economy. At present inadequate resources are channeled into land and land based economic activities (Andrew, Shackleton \&Ainslie, 2003). If "land reform will play a major role in increasing the abilities of rural people to become economically productive," (Department of ConstitutionalDevelopment, 2000), then surely there is enough reason to ensure that LED interventions are sustainable.

Given the fact that local economic development is still relatively new to local municipalities and is somewhat "fashionable" (Binns and Nel, 2001), the questions that this research proposes to answer are:

- How do municipalities ensure sustainability of local economic development initiatives in poor rural communities where land is one of the very few available resources?

- Are there any success stories that could be used as best practice modelsfor local rural municipalities to emulate?

- What opportunities are there and what challenges face land-based local economic development strategies in small rural towns? 


\subsection{AIMS AND OBJECTIVES}

With the background presented above, the main aim of the study was to explore some of the reasons why land-based economic development interventions struggle to meet their objectives of improving the livelihoods of local people. In exploring this, specific reference is made to the town of Groblershoop in the Northern Cape province.

The following specific objectives were set for this study:

- To document the livelihoods profile of the local community and determine whether land-based livelihood strategies are key to their survival strategies;

- To determine to what extent the Northern Cape province's provincial economic growth strategy incorporates land-based local economic development;

- To present a review of the local economic development strategy of the local municipality of Groblershoop and to document and analyze aspects that largely rely on use of agriculture and related activities; and

- Based on the review of existing projects, this study examines key opportunities and factors that impede the successful attainment of land-based local economic development objectives

\subsection{RESEARCH DESIGN}

\subsubsection{Rationale for the Choice of the Case Study Area}

Groblershoop is a small farming town. It is situated approximately $320 \mathrm{~km}$ North West of Kimberley, which is the provincial capital; and 120 kilometers from Upington. The area falls under the Siyanda District Municipality, which is fondly referred to as the "Green Kalahari". Groblershoop is situated in the middle of thethree main districts of the Northern Cape. These are: the Karoo, which is well known for its lamb exports; Siyanda, which is a grape exporting region; and the Frances Baardt region, which is well-known for its diamond exports.

The survival of the local economy of Groblershoop is straddled between the irrigation of lucern and grapes, as well as sheep and goat farming. The local municipality together with the provincial government has attempted numerous projects to stimulate the growth of the economy in the area -which is largely based on land and agricultural 
activities - in order to address the problem of unemployment and chronic poverty. These projects have had mixed results. While some are barely succeeding inproviding jobs to a small number of people, others have failed dismally. Groblershoop therefore provides a microscopic view of what is generally happeningin towns throughout the Northern Cape, with regard to local economic development and poverty alleviation interventions.

It is my opinion that an in-depth study of the situation in Groblershoop and athorough understanding of what is happening at the level of planning and implementation of LED initiatives, would provide valuable lessons for all who are working in the Northern Cape province in the area of LED. During my initial information gathering in preparation for this thesis, it was conveyed to me that the district municipality of Siyanda had recently commissioned a consultancy companyto develop a local economy strategy for the district. The consultants found that !Kheismunicipality, in which Groblershoop is located, was the most problematic municipality to work with. It is hoped that, through further investigation and research, a better understanding will be gained of the underlying problems that may frustrate development.

Having worked in Groblershoop for a while, there already existed a relationship between myself and the local community leaders. The consultants that have been commissioned to develop the LED strategy had also expressed their willingness to share the information they gathered from their own research. An added advantage was the fact that I had worked with both the mayor and municipal managers of !Kheis and Siyanda respectively. This background was of valuable assistance to the study. The target group for the research was community members involved in various government (i.e. local, provincial) LED initiatives; elected members of the local; and district municipalities, as well as the officials who worked on these projects.

It was expected that the study that was conducted by the consultants, which will become a public document when the district municipality council adopts it, would be a valuable resource. However, this was not the case as the documents were not ready at the time of completion of the research. Other studies that were conducted on the area and its LED potential are the provincial economic development strategy (when adopted officially), as well as the studies conducted by the provincial departments of 
Housing and Local Government. The provincial department of Agriculture has also developed an agricultural economic development strategy. As much as these studies may not have specifically focused on Groblershoop, it was expected that they would have looked at the Siyanda District Municipality and would have given some insight as to what the long-term plans are for LED in the area. Regrettably, this was not the case. It then limited the study to draft strategy documents and interviews with the relevant stakeholders.

\subsubsection{Summary of Methods}

This study relied extensively on the qualitative research method. It included:

- A review of literature on Local Economic Development;

- A review of provincial and local governments' LED plans and strategies;

- A review of Integrated Development Plans (IDP) of the Siyanda District and the Groblershoop local municipalities;

- A review of project plans and evaluations;

- Semi-structured interviews with target groups (e.g. project beneficiaries, government officials, municipal manager, town mayor, etc);

- A focus group-style interviews with key stakeholders; and

- Internet searches for information on the case study area and additional information on LED

An initial literature review was done in order to place into perspective the argument of the potential of LED to stimulate economic growth and thereby alleviate poverty. A brief reflection was also made on the international experiences of LED interventions and the current local practices within South Africa.

The method used was most suited for the research as it allowed for "analysis early in the research project, while still collecting data," (Neuman, 2000). By analyzing the data as it was collected, the researcher was guided into further data collection. Some insights gained from political leaders in the Groblershoop area on the available information were not as clear and concise as expected. This necessitated some 
changes in the approach used. The researcher was therefore compelled to compare the information gained from political leaders with the documented LED plans as presented in the IDP of the municipalities.

The purpose of group discussions was to get a better understanding of what people really felt about land-based LED initiatives as they are being implemented by government. It also allowed for the understanding as to how community members perceived the successes or failures of such projects. Since land is a highly emotive issue, the qualitative research approach was able to uncover the people's emotions and their thoughts on the potential of land to facilitate LED in their specific area.

As cautioned by Strauss and Corbin (1998), researchers who use qualitative research methods must be "flexible", which is what this researcher has tried to be. There were no rigid questions set out before the commencement of the interviews, rather some thematic areas were covered such as: the value of land in the Groblershoop community; and LED focus areas in the region and in Groblershoop in particular; etc. The initial interviews held with politicians and municipal officials greatly assisted the researcher with further guidance on questions to be asked in interviews with the specific target groups.

\subsection{SIGNIFICANCE OF THE STUDY}

Politicians, government officials, and community leaders alike are grappling with the problem of stimulating local economic development throughout the Northern Cape Province. Many projects are started and significant amounts of resources are pumped into them. Yet it has become a phenomenon in the province that as soon as these projects are launched, they collapse without producing any outcomes. Alternatively, the custodians of these projects - which in this case is the government - have to constantly provide more funding so as to ensure the continuation of these projects. Furthermore, land is one of the resources that the province has in abundance. It is believed that although the Northern Cape only constitutes 2\% of the country's population, it accounts for $30 \%$ of the landmass of the Republic of South Africa (Census 2001). Due to this fact, development practitioners in the province generally include land and land-use as the basis for many economic development projects. 
This study is aimed at shedding light on the reasons why land-based LED projects in the Northern Cape Province are not as successful as policy makers and planners had envisaged. Hopefully, the findings will assist policy makers and LED planners in making more informed decisions. The provincial Department of Agriculture and the regional office of the Department of Land Affairs are currently collaborating on land reform projects that would enable poor communities to create sustainable livelihoods for themselves. It is further intended that this study should assist the said departments by identifying the factors that impede on the successful implementation of projects for the achievement of objectives. Community leaders and non-governmental organizations alike may also find the findings of this study useful. Not only does it hope to highlight the objective reasons for the failure of projects, but this study also attempts to identify the attributing subjective reasons (community relations and dynamics).

\subsection{CONCLUSION}

This study sought to explicate the challenges in the context of sustainable land-based local economic development in poor communities of South Africa, using Groblershoop as a case study. It was found that although local municipalities operate as mandated by the Constitution to promote social and economic development, the five key dimensional imperatives which are clear policy guidance, institutional capacity building, intersectoral collaboration, political will and real empowerment appeared to be foundational and catalytic for sustainability. This finding concurs with work of (Kepe \& Cousins, 2002) where they argued that "although land reform will only be effective if imbedded within a broader programme to restructure the agrarian economy, this will not lead to significant reduction in rural poverty without a redistribution of political and economic power in favour of the poor." Indeed, it is recommended that a more robust and bold approach informed by sound research and pragmatic policy design linked to the five imperatives mentioned above is crutial for enhancing sustainable local government entities that favour economic empowerment and poverty reduction while increasing agrarian activity for social benefit.

\subsection{LIMITATIONS OF THE STUDY}

The study faced several limitations. Firstly, it was premised on the assumption that a comprehensive economic development strategy exists at both the provincial government and local government levels. Furthermore, since the province of the 
Northern Cape is predominantly rural and much of the economic activities of the small rural towns are based on agricultural activities, it was expected that these economic development strategies would make mention of land and land-use in stimulating LED.

As it will further be elaborated on in Chapter Four (See Sections

4.2 and 4.3) of this thesis, it was discovered that these documents do not exist both at local and provincial levels. While the provincial government does have a draft provincial economic development strategy, this document is currently being reviewed as part of the Provincial Growth and Development Strategy process. This has limited the extent to which the questions regarding the provincial government and municipality's recognition of the potential of land-based LED could be answered.

Secondly, the study was conducted at a time when there was immense fluidity and insecurity at both political and administrative levels in government. A considerable part of the research focused on municipal officials responsible for economic development planning and implementation, as well as local political leaders whowere responsible for LED. This provided a possible threat that the new incumbents would completely discard the plans of their predecessors, which will in turn impacton the degree of continuity and assessment of the project. An advantage is, however, that there will be no local government elections for at least 18 months.

Thirdly, the fact that 2004 and 2005 respectively, are years when national and local elections were and will be conducted, some community members could have seen this research as an electioneering attempt by government and therefore possibly not truthful in their responses when interviewed. While some were very positive towards the government, others were very outspoken about its failure to deliver on its election promises and continued support for community initiatives. However, the researcher has tried to do everything possible to fully explain the purpose of the study before any interviews were conducted.

Fourthly, this study relied extensively on government reports of projects implemented by particular departments. Since government departments are known for not being too responsive when requested to avail information (especially when projects have failed), some difficulty was experienced in obtaining the relevant information. 
Fifthly, in the absence of a higher education institution and a decent library in the Northern Cape, a significant limitation was experienced in doing a literature review. Since LED is relatively new in South Africa, it was difficult to find literature that provided some assessment of the failure and successes of, in particular, land-based local economic development initiatives.

Finally, the fact that the author has worked in the Groblershoop community as an official of the Department of Land Affairs, community members expected her to respond to questions of continued government funding and support for existing LED projects. She was also required to make certain commitments on behalf of the department of Land Affairs that more land will be purchased for the communities.

Due to the nature of the subject matter of this research and the potential limitations mentioned above, this study has limited itself to qualitative research methods such as interviews with specific target groups and reviews of secondary documents. 


\section{REFERENCES}

Africa, G. o. S., 1996. Constitution of the Republic of South Africa Act No. 108 of 1996, Pretoria: Government of South Africa.

Africa, G. o. S., 2000. Municipal Systems Act, No. 32 of 2000. , Pretoria: Government of South Africa.

Aliber, M., 2002. Poverty Eradication and Sustainable Development. Integrated Rural and Regional Development Research Programme, Cape Town: Human Sciences Research Council.

Andrew, M., Shackleton, C. \& Ainslie, A., 2003. Land use and rural livelihoods: Have they been enhanced through land reform?. Policy Brief, Volume 5, pp. 1-4.

Binns, T. \& Nel, E., 2001. Initiating 'Developmental Local Government' in South Africa:

Evolving Local Economic Development Policy. Regional Studies, 35(4), pp. :355-362.

Binns, T. \& Nel, E., 2002. Supporting Local Economic Development in Post- Apartheid South Africa. Local Economy, 17(1), pp. 8-24.

Congress, A. N., 1994. The Reconstruction and Development Programme. Johannesburg: Umanyano Publications.

Kepe, T. \& Cousins, B., 2002. Radical Land Reform is Key to Sustainable Rural Development in South Africa. Policy Brief, Volume 2.

Nel, E., 2001. Local Economic Development: A Review and Assessment of its Current Status in South Africa.. Urban Studies, 38(7), pp. 1003 - 1024.

Neumann, W., 2000. Qualitative and Quantitative Research Designs Social Research Methods: Qualitative and Quantitative Approaches. 4th ed. London: Allyn and Bacon. Statistics South Africa, 2001. Government of South Africa Census, Pretoria: Statistics South Africa..

Strauss, A. \& Corbin, J., 1998. Basics of qualitative research: Techniques and procedures for developing grounded theory. 2nd ed. s.I.:Sage Publications, Inc..

Tickamyer, A. \& Duncan, C., 1990. Poverty and Opportunity Structure in Rural America.. New York: Centre for Poverty Research. 